\title{
Situating on-farm apprenticeships within the alternative agrifood movement: Labor and social justice implications
}

\author{
Lorien E. MacAuley ${ }^{a}{ }^{*}$ and Kim L. Niewolny ${ }^{\mathrm{b}}$ \\ Virginia Tech
}

Submitted October 21, 2015 / Revised February 10 and March 16, 2016 / Accepted March 16, 2016 /

Published online April 8, 2016

Citation: MacAuley, L. E., \& Niewolny, K. L. (2016). Situating on-farm apprenticeships within the alternative agrifood movement: Labor and social justice implications. Journal of Agriculture, Food

Systems, and Community Development, 6(2), 195-223. http://dx.doi.org/10.5304/jafscd.2016.062.024

Copyright (C) 2016 by New Leaf Associates, Inc.

\begin{abstract}
The beginning farmer phenomenon offers an array of possibilities for facilitating social, economic, and political changes in the agrifood system. Apprenticeships within both formal and informal institutions are increasingly important in the education and social connectivity of beginning farmers. Although apprenticeship opportunities are popular for "new farmers," "aspiring farmers," and their on-farm hosts for a number of reasons, a critical approach is necessary in the design and nature of

\footnotetext{
a * Corresponding author: Lorien E. MacAuley, M.S., PhD Student, Department of Agricultural, Leadership, and Community Education (0343); 228 Litton-Reaves Hall, 175 West Campus Drive; Virginia Tech; Blacksburg, Virginia 24061 USA; +1-703-789-7748; lorien@,vt.edu

b Kim L. Niewolny, Ph.D., Associate Professor; Department of Agricultural, Leadership, and Community Education (0343); 282 Litton-Reaves Hall, 175 West Campus Drive; Virginia Tech; Blacksburg, Virginia 24061 USA; +1-540-231-5784; niewolny@vt.edu
}

these experiences, in light of inequitable structural conditions that may reproduce potentially insurmountable barriers to new farm entry and sustainability. Drawing upon alternative agrifood movement discourse and social reproduction at work within critical traditions of sociocultural learning, we illustrate on-farm apprenticeship learning from a critical perspective in order to better describe and understand this form of beginning farmer education. We share findings from a mixed-methods empirical study of on-farm apprenticeship learning in Virginia, where we focus on the practices, structures, and institutional activity that inform on-farm apprenticeship experiences. This study sought to answer the questions: what kinds of on-farm apprenticeships

\footnotetext{
Author note

We report no known conflicts of interest and had no external funding for this research. All research activities were conducted in accordance with the Virginia Tech Institutional Review Board.
} 
are available, to whom, and in what ways? Also, what are important educational practices, structures, and/or institutions that support on-farm apprenticeship learning? Data are derived from qualitative interviews of host farmer/educators, on-farm apprentices, and new farmers who were recently apprentices; and from a quantitative survey of Virginia farmers who host apprentices. Our findings situate on-farm apprenticeship within a broader discourse about farm labor, as we open the discussion surrounding the relationship between difficulties experienced by small, diversified farms in meeting their labor needs, and the growing popularity of the apprenticeship model on individual farms. We also explore how cultural whiteness within alternative agrifood movements (AAMs) translates to low inclusivity of historically underrepresented groups, and consider how the low- or no-pay model for the tenured duration of the apprenticeship may affect structural barriers to entry for members of low socioeconomic groups, within on-farm apprenticeship and thus within beginning farmer education. Through the themes that emerged in our study, we posit considerations for social justice implications of on-farm apprenticeship, offer several recommendations for the practice and planning of on-farm apprenticeship, and lay groundwork for future exploration of the ways in which the apprenticeship model may reproduce equitable learning spaces.

\section{Keywords}

adult education, alternative agrifood movement, apprenticeship, beginning farmer, farm labor, social justice

\section{Background}

The beginning farmer phenomenon has developed into a burgeoning number of programs, policies, and grant opportunities, which provide the structural footing to ease barriers and create possibilities for new and sustainable farm entry (Ahearn, 2013; Niewolny \& Lillard, 2010; Sureshwaran \& Ritchie, 2011). The perspectives and politics within beginning farmer program development and training are many, and include issues ranging from fair and equitable access to labor, access to scaleappropriate markets, start-up capital for resilient economic performance, land tenure and farm succession, and support structures and knowledge systems for ecological farming practices (Ahearn \& Newton, 2009; Henderson \& North, 2011; Parsons, et al., 2010; Thilmany \& Sureshwaran, 2011). Despite these mounting challenges, beginning farmers and ranchers are diverse in age, racial, gender, class, and ethnic distinctions, and vary widely in farm scale, scope, and geography (Meyer, et al., 2011). Beginning farmers on average also operate smaller farms, in both size and gross dollars, compared to established farmers (Ahearn, Yee, \& Korb, 2005). Although they tend to be younger than established farmers, about a third of beginning farmers are at least 55 years or older (Ahearn \& Newton, 2009). The average age of a principal farm operator is now 58.3 years, an increase of 1.2 years since 2007, continuing 30 years of steady increases (U.S. Department of Agriculture, National Agricultural Statistics Service [USDA NASS], 2014). At least 40 percent of all U.S. farms are operated by beginning farmers, limited-resource, and socially disadvantaged farmers, (Nickerson \& Hand, 2009; USDA, 2014). Beginning farmers thus are increasingly recognized as a distinct group with different programming needs when being targeted by agricultural service providers for education and technical assistance efforts.

The beginning farmer conversation has not grown in isolation from other agrifood system issues and discourses. Grassroots, policy, and academic circles increasingly are creating ample spaces for the emergence of alternative agrifood movements (AAMs) (Allen, 2004; Constance, Renard, \& Rivera-Ferre, 2014; Goodman, DuPuis, \& Goodman, 2012). The alterity of this movement stems from its challenge to dominant agricultural trends of large-scale, centralized processing and distributing models; increased farm mechanization; reliance on input-intensive, low-diversity biophysical production practices; unexamined ethical arrangements; and different considerations for the nutritional and aesthetic qualities of food (Constance, et al., 2014; Goodman, et al., 2012).

Within AAMs, we see initiatives with diverse emphases, ranging from economic development, social justice, and environmental sustainability, to 
those that integrate a wide range of system-level issues that embrace expressions of local/regional food systems (Clancy \& Ruhf, 2010), community food systems (Slocum, 2007), and community food security (Hamm \& Bellows, 2003). Beginning farmers' attention to these issues undergirds, albeit in complex ways, beginning farmer manifestations of practice and their transformative potential. This, in turn, reciprocally informs and re-informs agrifood discourses. These discourses emphasize the ways beginning farmers and other actors play a significant role in contributing to the vitality of small and midsize farms, production and distribution of locally and regionally produced foods, and ecological resilience, and providing access to socially just, healthful food, in both urban and rural landscapes.

Apprenticeships are emerging in various contexts as social seedbeds of cultural connections for the next generation of agriculturalists. Informally and/or nonformally structured on-farm apprenticeships are an increasingly popular approach to beginning farmer education (Hamilton, 2011; Kalyuzhny, 2012; Niewolny \& Lillard, 2010). For the attention they have received, however, there is relatively little empirical and theoretical understanding of on-farm apprenticeship experiences (especially those outside of college- and universitybased student farms), and the implications they may have for the reproduction of structural conditions that govern farm entry, continuance, and long-term viability.

The purpose of this paper is to begin to illuminate and describe on-farm apprenticeships from a critical perspective, rooted in AAM discourse. To that end, we illustrate findings from a concurrent mixed-methods study of on-farm apprenticeship learning in Virginia, in which we viewed on-farm apprenticeship learning from the lived experiences of apprentices and host farmers. This study sought to answer the questions: what kinds of on-farm apprenticeships are available, and to whom, and in what ways? Also, what are the most important educational practices, structures, or institutions that support on-farm apprenticeship learning? Through analysis of empirical data of the phenomena, we posit considerations for social justice implications of on-farm apprenticeships and lay groundwork for further exploration of the ways in which the apprenticeship model may reproduce inequitable learning spaces in agriculture.

\section{The Socio-Historical Context of Beginning Farmers}

As the United States experiences a long-term rising average age of farmers (Dimitri, Effland \& Conklin, 2005), fewer beginning farmers are entering agriculture each year (Ahearn, 2013). There is a growing awareness that in order for new farmers to enter farming, agricultural education systems and policies must better address emerging issues for beginning farmers. Ruhf (2001) and others (Ahearn \& Newton, 2009; Henderson, \& North, 2011; Parsons et al., 2010; Thilmany \& Sureshwaran, 2011) have identified key challenges as access to financial capital and credit; suitable farmland and tenure options; size-appropriate and economically viable markets; and culturally appropriate networking, training, and technical assistance. In response to the call for better beginning farmer preparation, in recent years a body of federal and state programming and policy has arisen (Sureshwaran \& Ritchie, 2011). For example, the Virginia Beginning Farmer and Rancher Coalition Program is a statewide coalition working to develop, coordinate, and offer curriculum and training, resources, farmer-to-farmer mentoring, and capacity-building for educators and service providers; countless other beginning farmer initiatives have emerged over recent years to provide adult education and resources for a diversity of beginning farmer communities, and to address start-up and sustainability aims (Niewolny \& Lillard, 2010).

\section{Alternative Agrifood Movements}

It is clear that beginning farmers face a complex web of barriers. However, the ways in which these challenges and issues are discursively and politically brought to the forefront are equally important in order to enable new material and political possibilities in our farming communities (Niewolny \& Lillard, 2010). For instance, similar to a number of agrifood system experiences in recent years, the beginning farmer phenomenon in North America has been informed in part by the development of alternative agrifood movements (Allen, 2004, 2008; 
Niewolny, 2007; Niewolny \& Wilson, 2007), which envision an alternative to the dominant agrifood system. AAMs reflect an array of issues and include a diversity of actors who challenge the dominant structures and modes by which food is produced, processed, delivered, and consumed (Carolan, 2012; Lyson, 2004; Sbicca, 2012). AAM discourses also critically engage with the politics of labor, land, markets, and knowledge. New spaces thereby have emerged as alternatives to the dominant food system; there has been a groundswell of academic, policy, and grassroots activity and critique in response to the social, economic, and ecological unsustainability of the modern industrial agrifood system (Carolan, 2012; Sbicca, 2012). For Constance, Renard, and Rivera-Ferre (2014), the AAM discourse comprises four domains in which program and policy activity emphasizes continued system change: improvements to the biophysical environment; support for viable agrarian communities; concern for quality of food (nutrition and taste); and emancipation and social justice aims. AAMs and their material realities, however, have been criticized for their own injustices and noninclusivity (Allen, 2004; Guthman, 2008a; 2008b; Hinrichs \& Allen, 2008; Slocum, 2007). For instance, Slocum (2007) calls out the often unexamined cultural whiteness of AAMs. For Guthman (2008a) and Allen (2004), the issue of inequality embedded within AAMs is a core concern; therefore, the manner in which we focus attention and act on racial, gendered, and class relations within alternative agrifood systems and processes is increasingly significant. For example, farm labor and farmworker issues are becoming increasingly visible within the literature (Allen, 2008; Carolan, 2012; Cavalieri, 2011; Guptill, Copelton, \& Lucal, 2013; Holmes, 2013). Lavin (2009) and Guthman (2008b) write about how AAM discourse may unwittingly embrace and reinforce hegemonic neoliberal dogma. Relatedly, Hinrichs and Allen (2008) are concerned with the way in which AAM activity often excludes the voices and experiences of those who lack the economic wealth to fully and equitably participate. These critiques underscore the fact that the AAM discourse, widely defined, is laden with social justice and anti-oppression concerns (Carlisle, 2014;
Feenstra, 2002; Sbicca, 2012) in a reimagining of our relationship with food (Guptill, et al., 2013).

In many ways, AAMs have made spaces for alterity and possibility (Goodman et al., 2012). We argue that the expressions of the values, practices, and material outcomes of AAMs have important implications for beginning farmers, who must navigate this labyrinth. With this movement as our frame, we now turn toward one aspect of the beginning farmer experience-on-farm apprenticeships-and how they are situated within the beginning farmer phenomenon.

\section{Apprenticeships as Sites of Social Reproduction}

An apprentice is, generally, an indentured novice learner who works alongside, pitches in, observes, and interacts with an expert, which ultimately leads the novice to mastery in a given set of skills and knowledge (Paradise \& Rogoff, 2009). Individual farms throughout the U.S. have been increasingly implementing apprenticeships (Niewolny \& Lillard, 2010), occasionally with technical support from Cooperative Extension and/or nonprofit entities (see, for example, Carey et al., 2006). They may be more common on small, labor-intensive, sustainability-oriented farms (Endres \& Armstrong, 2014; Hamilton, 2011; Pilgeram, 2011; Powell, 2007), who may view apprentices as a critical source of inexpensive farm labor (Pilgeram, 2011; Kalyuzhny, 2012; Wood, 2013).

Apprenticeship-type programs also are implemented increasingly on the student farms of colleges and universities. Experiential learning within apprenticeship promotes horizontal learning opportunities (Leis, Whittington, Bennet \& Kleinhenz, 2011; Parr \& Trexler, 2011). While apprenticeship programs on student farms at colleges and universities have been demonstrated to be successful in formal higher education, few studies have examined the learning in apprenticeship programs on individual farms.

On-farm apprentices are learning by doing, by experience, in situ. Niewolny and Lillard (2010) call for more focus on participatory, situated, and experiential learning approaches that integrate beginning farmer knowledge with, in, and from lived experiences on-farm, as in an apprenticeship. In embracing a situated view of learning, 
apprenticeship learning is thus a means to explore the construction of socially structured and culturally mediated processes of knowledge and power (Lave, 1988). Because apprentice learners co-construct meaning and identities through social negotiation with actors and structures, there is potential for unreflective social reproduction of existing power relations (Dewey 1938/1986; Foley, 1999; Freire, 1972).

Therefore, important questions have been raised about the political expressions that occur in and/or from on-farm apprenticeship experiences. While small farmers may depend on apprentices as a source of inexpensive labor, the low pay or lack of pay for the duration of the apprenticeship may create financial disincentives for would-be participants from socially disadvantaged groups (Pilgeram, 2011; Wood, 2013). On-farm apprenticeships, if located within AAMs (as Hamilton [2011] and Pilgeram [2011] suggest), may share the problematic race- and class-based imbalances found in AAMs (Allen, 2004; Etmanski, 2012; Guthman, 2008a; Hinrichs \& Allen, 2008; Sbicca, 2012; Slocum, 2007). For example, as Bourdieu (1984) theorizes, social preferences are often influenced by class habitus, an often unconscious socialization of skills, preferences, and meanings, formed from social interaction and informed by our social position. Althusser (2006) writes that there are many social forces that act unconsciously to perpetuate value systems that maintain the dominant social order. Following the work of Giroux (1992), Lather (1991), and Freire (2005), learning is not a politically neutral act. Instead, it is laden with cultural politics that may enact hegemonic narratives and validate dominant knowledge regimes, at the expense of marginalizing less visible ways of knowing. Apprenticeship, therefore, from this radical educational view, is a charged political ground upon which socially reproductive forces play out, and so it requires further attention.

Thus, if on-farm apprentices are steeped in a particular social system, with possibilities for raceor class-based inequities, they may unknowingly contribute to their replication. Our research is therefore oriented to problematize and examine on-farm apprentices, and consider how the activity of on-farm apprenticeship is situated within the dynamics of AAMs and food system politics more widely. We seek here to provide enough momentum for further analysis and exploration, toward improving on-farm apprenticeship practice in the long term.

\section{Methodology}

Given the dearth of empirical research into onfarm apprenticeships for beginning farmer education, we undertook an exploratory, descriptive study. The study was informed by the multiple realities within Lincoln and Guba's (2000) historical realist ontology and transactional/subjectivist epistemology, while embracing Deweyan pragmatism (1938/1986). Framing the study as such, we chose to employ a concurrent mixed-methods approach in order to view on-farm apprenticeships within both qualitative and quantitative paradigms (Creswell, 2009). We employed Greene's (2007) stance of complementary strengths, where the independent datasets were used in tandem to infer results.

Qualitative data allowed us an in-depth look into the lived experiences and activities of those involved in on-farm apprenticeships. Quantitative data, as a backdrop for the population under study, enabled us to examine the likely incidence and prevalence of lived experiences and activities, so we could judge their importance in agriculture more holistically. Interview protocols and the survey instrument were derived from a content analysis of three handbooks or guides (Jones, 1999; Mills-Novoa, 2011; Powell, 2007) aimed at advising farmers who host apprentices. For purposes of this study, an on-farm apprentice is defined as someone who is an apprentice, intern, on-farm student, etc.; is over 18 years of age; can be paid or unpaid; and importantly, for whom there is an express agreement that the farmer will teach them how to farm.

The geographic scope of the study was the Commonwealth of Virginia. Participants for both the survey and interviews were recruited through email distribution lists operated by Virginia Cooperative Extension, the Virginia Beginning Farmer and Rancher Coalition Program, the Collaborative Regional Alliance for Farmer Training (CRAFT), ATTRA, and at agricultural events such as the 
Virginia Farm to Table Conference, the Virginia Biological Farming Association Conference, and Virginia State University's Small Farm Family Conference.

The qualitative strand consisted of semistructured interviews with on-farm apprentices $(n=5)$, farmers who host apprentices $(n=5)$, and farmers who were recently on-farm apprentices $(n=2)$. Interviews lasted from 50 to 82 minutes, were audio-recorded, transcribed verbatim, and coded using Atlas.ti software, via a semi-open coding scheme (Hsieh \& Shannon, 2005). The interviews and coding process were based around theoretical constructs of policies and institutions supporting on-farm apprenticeships, backgrounds of participants, educational and teaching practices, constructs of learning theory, and values and beliefs. Please see Appendix A for the interview protocol.

The quantitative strand consisted of a selfadministered survey of Virginia farmers who host apprentices. Survey instrumentation followed Babbie $(1990,2010)$ and collected data on apprentice characteristics, details of the apprenticeship program, and background of the host farmer and farm. The survey was disseminated online and in paper form, and elicited a total of 55 responses, with 45 responses ultimately validated. Each response represents a farm that hosts apprentices in Virginia. The precise survey response rate is unknown, because agricultural service providers assisted with dissemination to their contacts. At the time of the survey, only 104 farms that host apprentices could be identified in Virginia; thus 43 percent of known host farms provided valid responses. The survey was disseminated in person at statewide farmer events, and via email, with two follow-up email reminders in an effort to increase the number of responses. Survey data was then compiled and analyzed in Statistical Package for Social Sciences (SPSS) software, using mainly descriptive statistics and paired sample t-tests (2tailed) where appropriate. Please see Appendix B for the survey instrument.

The qualitative and quantitative data sets were mixed in the analysis phase of the study. Results of each dataset were used together complementarily to infer an authentic description of on-farm apprenticeships (Greene, 2007; Lincoln \& Guba,
2000). In this way, both sets of data were triangulated to derive meaningful results to answer our guiding research questions.

\section{Findings}

On-farm apprentices and host farmers shared information about their backgrounds, their experiences learning and/or teaching on the farm, beliefs and values about the agrifood system and their aspirations as they relate to educational practices, structures, or institutions that support on-farm apprenticeship learning. Due to the exploratory design of this study, findings are not intended to be generalizable, but they may be considered to represent the participants in the study, each in his or her unique position in Virginia. Findings are shared below.

\section{Who Hosts On-farm Apprentices?}

Farmers who responded to the survey $(n=45)$ were mainly the principal operators of the farms hosting the apprenticeship program (87.5\%), while other respondents were in management roles on the farm. In the survey, 100\% of farmer respondents self-identified as White. There was a roughly even split between female (45\%) and male (55\%) farmers who completed the survey. Of farmer hosts, $92 \%$ have attended some institution of higher education, and $77 \%$ have earned college degrees. Also, $19 \%$ of farmer respondents have earned advanced degrees from institutions of higher education.

Survey respondents were asked to report their motivations for hosting apprentices on a 4-point Likert scale from "not important" to "very important." A paired-sample t-test (2-tailed) was used to compare answers, thus determining significant consensus within a response. Paired sample t-tests (2-tailed) showed that the top motivation by far $(p<0.01)$ was "I need labor for my farm," which $98 \%$ rated as "important," and 73\% rated as "very important." As one farmer put it, apprentices may be seen as sources of "cheap labor":

There's people who have a small farm, and are often just starting out, and are still small, and they want labor, and they think that they can offer some sort of educational experience in return, for cheap labor. 
(Farmer)

Another farmer further stressed this point:

And so make no bones about it, they're here to operate the farm. (Farmer)

Another farmer also spoke of apprentices as an inexpensive labor source:

They're going to work hard here, um, you know, at not a lot of pay. (Farmer)

Also, the following apprentice spoke about being treated like an employee, but not getting paid as well as an employee would:

You kind of start to think about it, and it's like, well, I'm not technically an employee. I'm an apprentice. You know, I'm getting paid, like, maybe five bucks a day for this work. How much can you enforce that type of labor restrictions on me, you know? We were apprentices treated like employees. And I think that's true of a lot of farms.

(Apprentice)

So survey and interview data indicate that responding farmers viewed apprentices as a source of inexpensive farm labor.

In general farmer respondents hosted apprentices on small, diversified farms, which were diversified in production as well as in marketing. The reported median annual sales volume of host farm respondents was US\$60,000. The majority of survey respondents were on fewer than 50 acres (20 hectares) of total land farmed (leased and owned). Survey respondents also tended to grow a diverse range of products, with the majority raising vegetables, poultry-based products, and fruits. Respondents sell an average of three types of agricultural products, a figure which counted all vegetables as one product, and all fruits as one product. Of farmer educator/host respondents, 74 percent raised vegetables, 51 percent raised poultry and eggs, and 49 percent raised fruits. Very few grew soy, corn, or wheat. Survey and interview respondents also showed a tendency towards diversified marketing strategies and direct, local marketing of their products. Respondents reported marketing through, on average, 2.9 different outlets, which were most commonly community supported agriculture operations (CSAs), wholesale outlets, farmers markets, and restaurants.

\section{Who Are the Apprentices?}

Farmer survey respondents were asked to report demographic data on current and former apprentices. They reported a fairly even split between female $(56 \%)$ and male (44\%) apprentices, and average age of 24.0 years. Apprentices showed low reported racial diversity, with apprentices mostly reported as White $(93.9 \%)$, followed by apprentices of Spanish, Hispanic, Latino origin (2.3\%), Black or African American background (1.8\%), Asian background $(1.8 \%)$, and less than $1 \%$ of apprentices were of American Indian, Alaskan Native, Native Hawaiian, or Pacific Islander background. All participants in interviews identified as White, despite attempts to recruit a diverse group for interviews. Thus both on-farm apprenticeships and farm host participants in this study were disproportionately White.

The data also reflect a high level of formal educational attainment among those involved in on-farm apprenticeships. Eighty-four percent of on-farm apprentices have attended institutions of higher education, while 64 percent have earned a college degree.

Additionally, host farmer survey respondents reported that apprentices are typically not from a farming background, and they do not have farmland in the family that they may inherit. Very low standard deviation around these responses indicates significant consensus. Respondents also reported that apprentices typically had between zero and two years of farming experience prior to starting the apprenticeship program, with the average experience being four months; the mode (most common) response was 0.0 years of farming. The data therefore suggest that apprentices had little experience with farming prior to starting their apprenticeship programs. Interview data also suggests this conclusion. One farmer stated:

Interviewer: So do you think most of the apprentices are from farming backgrounds, or are they-? 
Farmer: I think most of them are not...But it does seem like many people in the organic, sort of sustainable movement, smaller-scale are not from that background. (Farmer)

The above farmer not only reinforced that the association of apprenticeships with a "sustainable movement" but asserted that apprentices are often not from a farming background. One apprentice described his perception of the background of most apprentices:

I grew up in the city and I had no experience with farming for most of my life, and then my first exposure to it was in college... Most [apprentices] are more like me, and a little bit of college community garden volunteer stuff, where they really didn't know much. Like you don't know anything at that point. And some have had like up to two seasons on organic farms, or like college farms. (Apprentice)

According to this apprentice, his background was typical of other apprentices, who do not have a farming background. Thus both survey and interview data convey participants' sentiments that apprentices normally have little experience with, and little prior access to, agriculture.

Additionally, interviews suggested that the physical and financial circumstances surrounding the apprenticeship experience will exclude those who lack funds. In interviews, apprentices and host farmers discussed the need for savings or other financial support in order to complete an apprenticeship. The below apprentice discussed costs associated with the tenured duration of an on-farm apprenticeship:

There's still transportation. Usually you have to own your own vehicle if you want to get off the farm... you know, there's gas [you need to buy]. While I was there we could eat whatever vegetables we wanted, but there was still a decent amount of food expenses to eat well. Um, so I mean, I think you could do it... But if you think of somebody who might have come from a low-income or single-parent family, they want to be a farmer... they probably need to work a job that pays them. (Apprentice)
The apprentice above reflected on the costs associated with receiving no or low pay for the duration of the apprenticeship, and that it would likely not be as possible for members of low socioeconomic groups. The below on-farm apprentice described her thoughts related to the financial realities of being in the apprenticeship:

The people who can afford to take the financial risk of doing apprenticeships are people who have either done a great job at saving money, or have had the support of their families while they're in school or while they're in the apprenticeship. And so that makes apprenticeships only accessible, usually, to people who come from well-off backgrounds.

(Apprentice)

In the above, we see apprentices reflecting that they would not be able to enter an apprenticeship if they lacked the financial security from funds derived elsewhere.

\section{Structure of Apprenticeship Programs}

Host farmers who responded to the survey reported that the average length for the apprentice on the farm was 20 weeks, but this varied widely, from one week to one year. Respondents hosted, on average, two to three apprentices on their farm at one time. Approximately four out of five respondents provided some sort of housing for apprentices, and approximately half of farmers provided on-farm housing in a separate building from their own homes. Although survey respondents agreed highly with the statement, "I provide stipends or other monetary compensation for apprentices," interview data uncovered the theme that apprentices, while perhaps receiving some compensation, are often paid less than minimum wage. One apprentice discussed low pay:

[Pay was] less than minimum wage, when you add up all the hours. It was a stipend... I think, it was like a few hundred dollars a month, or 500 dollars a month. (Apprentice)

Another apprentice described low pay and working conditions: 
[Farmers] pay their workers 200, maybe 300, 400 dollars a month with very basic living quarters, so that they can make a profit... You're working 50, 60 bours a week. (Apprentice)

In this view, both survey and interview data suggest that some apprentices were receiving pay, but likely less than minimum wage.

Survey respondents were asked to rank how often they provided certain educational activities to apprentices on a four-point Likert scale. Overall, farmers were verbally explaining and demonstrating tasks, working side by side, and giving oneon-one feedback, rather than providing school-like or written activities $(p<0.01$, via paired sample ttest, 2-tailed). However, apprentices had mixed reports about the focus on work as education. Some apprentices spoke positively about the farm work:

That's what I loved about the farm apprenticeship, is like, what better way to learn to farm, than to farm? It gets ingrained in your muscles... You learn it in your body. (Apprentice)

In contrast, others critiqued the focus on labor over learning:

When you go to a commercial organic farm apprenticeship, you're not going to learn that much, because the farmer is focusing on using you as a laborer, and not focusing on teaching. (Apprentice)

The farmer below echoed the concern that using apprentices as farm labor is often a problem for the apprentice, while farmers "need the labor," and have few options to meet labor needs:

[Host farmers] know they need the labor, they know an apprentice is low cost, you know, when you're talking about dollars, but it doesn't always work. out. Like maybe they're not really good at communicating, or teaching, you know, or like I said, the living situation is just very bad for the intern, or the intern thinks it will be much more romantic than the actual grunt work is going to be, you know? (Farmer)
Another participant addressed her systematic concerns with the common use of apprentices as labor, pointing to larger problems beyond the individual farm scale:

The apprentices want to learn as much as they can, but the farmers are deriving their workforce off of young people wanting to learn for next to no money. And that's how sustainable agriculture is being successful right now ... and I don't know if that's the type of farming system that's going to make it in the long run. (Apprentice)

In this apprentice's words, farmers are indeed seeing apprentices as an inexpensive source of labor, yet those practices may not "make it in the long run." Below an apprentice showed awareness of the fact that the labor for low or no pay makes the farming system possible:

Yes, a farmer is giving you an education, but if there were no apprentices, the farm wouldn't be able to exist. So in sustainable agriculture, farmers are completely dependent on this apprenticeship.

(Apprentice)

In the above, we see apprentices reflecting on their financial situation, and both farmers and apprentices reflecting on the primary role of apprentice as farm laborer. Linking survey and interview data together here supports the idea that the host farmers viewed apprentices as inexpensive labor for the farm upon which they may come to depend.

\section{Apprenticeships as Embedded in Alternative Agrifood Movements}

Apprentices and farmer hosts alike invariably showed knowledge and consideration of AAM discourses, as described by (Constance, et al., 2014). In their interviews, apprentices shared a feeling that they were not just learning farming but were a part of the activities of the larger food system, in which they are also intellectually interested. One apprentice put it simply:

So that's a little bit about me, a little bit about how I got into this food system world. Beyond that, just 
my own personal interest with local foods and eating bealthy and cooking and connection to food.

(Apprentice)

This apprentice described not only how she got involved in an apprenticeship but how she felt that she was a part of a larger body, which she characterizes as a "food system world." Many apprentices also explained their entry into agriculture through a critical engagement with the food system in formalized education, such as a college or university. This apprentice explained her interest:

\section{So when I went to [University], I began to kind of learn about factory farming and food systems, and of course instantly became a vegetarian, and a food rights activist, and just started really educating myself about what was happening in the world. (Apprentice)}

The above quotation demonstrates the interplay between learning about broader food system issues in an abstract, conceptual way, and desiring to engage with the food system hands-on. As one apprentice said:

I haven't quite determined what my role in this movement will be yet... I know that I want to live my life by those ideals of sustainable agriculture, and be a part of the food process, the journey. (Apprentice)

We see that this apprentice considered herself to be in a movement. The next apprentice also stated how his interest in apprenticeships was oriented not merely around obtaining training to an end, but that it was also an expression of his involvement with AAMs:

That was a buge driving force, was to figure out how to live in a way that we could have that world... less pollution, more biological diversity, cleaner world, bealthier people. (Apprentice)

The apprentice above was motivated to undertake an apprenticeship due to his consideration of the environment and food-quality concerns raised and publicized by AAMs (Constance, et al., 2014).

Farmers also expressed that they view hosting of on-farm apprentices as informed by AAMs, and also were knowledgeable and conversant in AAM discourse. One farmer, when explaining why her farm decided to host apprentices, said:

That's the power of small-scale, really localized sustainable — meaning biological, ecological methods...We believe in this so wholeheartedly that this is a good thing, for our country, our communities to feed ourselves, and it's not going to bappen without deliberate education and training about these methods... and we wanted to contribute to that.

(Farmer)

This farmer explained the desire of her farming partner and herself to spread their type of farming, which is driven by critical engagement with the agrifood system. The statement evokes the agrarian question of AAM discourse in her expression of value in community, while also echoing the environmental question in the value she placed on "biological, ecological" methods (Constance, et al., 2014). The next farmer shared:

When [my farmer partner] heard what Will Allen was doing, he was very interested in working with kids here on the farm. And it's a good place to bring them, and we think sticking your hands in the dirt and doing stuff like that is good therapy. (Farmer)

The identification with Will Allen of Growing Power (Broadway, 2009) engages the progressive messaging of AAMs and shows that the desire to host apprentices was perhaps motivated by a social cause. Another farmer noted that his farm engaged apprentices in building community:

Part of our mission is to build community, and so all the group facilitation skills and facilitation skills are really important to that so I think it's not just—it's vital to our mission to teach those skills anyway. (Farmer)

By teaching facilitation skills, he said that his farm is also moving its mission of building 
community forward, which shows engagement with the agrarian question. The next farmer also related AAMs to the farm's mission:

$$
\begin{aligned}
& \text { I got involved in small-scale organic farming right } \\
& \text { after college... and so we're into teaching people } \\
& \text { about an extreme minority in food production in the } \\
& \text { country today, and here are the reasons we think. it's } \\
& \text { best_ nutrition, taste, freshness, environment, all of } \\
& \text { that. (Farmer) }
\end{aligned}
$$

So the farmer above engaged with the environmental the food-quality concerns of AAM discourse, and once again related it to the motivation to host apprentices. The theme that emerges is that these farmers were linking their hosting of apprentices to their AAM practice. Thus apprentices and farmers alike reflected AAM discourse in their motivations to undertake and host apprenticeships on a farm. This theme shows that hosting and participating in an on-farm apprenticeship are connected in part to a larger emphasis on critique and intellectual engagement in the food system.

\section{Former Apprentices Starting Their Own Farms} Of host farmer survey respondents, 43 percent reported that they knew of apprentices who had gone on to start their own farms after their apprenticeship. A total of 57 apprentices represented in survey data reportedly went on to start their own farms. Some host farms reported as many as eight former apprentices having gone on to start their own farms. The fact remains that relatively few former apprentices in this study reportedly went on to start their own farms. They may still be engaged in AAMs, however, as the farmer below explained:

\section{Of the maybe 30 to 35 people who had been through the program, only like two or three were actively farming as a full-time job...not a great track record. And all those [apprentices], they went on to be activists or educators or researchers or just eaters, so in a sense, that's great, but at least with [farm name]...we still struck out more than we bit. (Farmer)}

This farmer stated that while many apprentices went on to be engaged intellectually with food system work, he lamented that more apprentices did not go on to begin farming.

\section{Summary of Findings}

In summary, on-farm apprenticeships took place mainly on small, diversified farms. Farmer and apprentice participants in this study were disproportionately White, with high educational attainment. Apprentices were from a non-agrarian background and had low access to farmland. Host farms often provided housing and low or no pay. Farmers, who were motivated to host apprentices chiefly by a need for labor, provided task-oriented, on-the-job learning, with little formalized instruction. Participants expressed concern that farmers may need the inexpensive or free labor of apprentices to meet their labor needs, an arrangement critiqued by interviewees. Apprentices and host farmers alike saw themselves as part of a social movement within AAM discourses, and were motivated by critical engagement with the agrifood system. Few former apprentices may continue as beginning farmers themselves. These findings represent only the participants in this study, but are nonetheless telltale indicators for on-farm apprenticeships and provide several points for further discussion.

\section{Discussion}

\section{On-farm Apprenticeships as Sites of Participation in Alternative Agrifood Movements}

Our findings suggest that apprentices, and the farmers who host them, consider themselves to be part of a broader social movement, expressing knowledge of and familiarity with alternative agrifood discourses. These findings corroborate others, who write that on-farm apprentices and other farm volunteers are motivated by ideologies and practices of a larger social movement (Hamilton, 2011; Niewolny, 2007; Pilgeram, 2011; Terry, 2014; Wood, 2013). Alternative agrifood discourses have been theorized by Constance et al. (2014), Guptill et al. (2013), Allen (2004), and Sbicca (2012) to include many threads related to the environment, agrarianism, food and dietary quality, and emancipation and social justice. Participants in this study consistently echoed values and 
criticality in these areas. Additionally, while many different ideological orientations exist within AAMs (Sbicca, 2012), farmers who engage in AAMs are likely to be small, diversified, and directmarketing operations (Carolan, 2012; Lyson, 2004), much like those who hosted apprentices in this study.

Study participants were generally not from a farming background and had little access to farmland. These findings were consistent with other literature, which suggests that beginning farmers increasingly experience significant barriers to accessing farmland and do not grow up in agricultural communities (Ahearn, 2013; Kalyuzhny, 2012; Meyer et al., 2011; Sureshwaran \& Ritchie, 2011; Wood, 2013). However, through apprenticeship, novices with little access to agriculture gain entry into the knowledge systems of agriculture, socioculturally co-constructing new knowledge about farming and food within the context of their apprenticeship. Although not many of our study participants continue as beginning farmers after the apprenticeship concludes, the apprenticeship experience may be important in other ways, informing apprentices' ongoing participation in the critical work they engage in with AAMs, or increasing agricultural literacy and know-how.

Our study therefore shifts the focus away from understanding on-farm apprenticeships as simply job-training and a pathway for farm entry. Instead, apprentices in the study were primarily motivated to undertake an apprenticeship out of a value for and desire to critically engage in improving the food system, or create alternatives to the dominant food system. The individual apprentices and host farmers in this study, then, are better seen as change agents who seek to transform agriculture to more closely align with principles of AAMs through the social reproduction occurring through beginning-farmer educational activity within their farms and communities. However, these highly motivated individuals may be constrained in their transformative potential, based on the many structural issues governing agriculture, which this study highlighted.

\section{Political Entry and Accessibility of On-farm}

\section{Apprenticeships}

This study did not inquire as to the income levels of participants, but their high educational attainment is a statistically positive indicator of middleto upper-class socioeconomic backgrounds (Bailey \& Dynarski, 2011; DeNavas-Walt \& Proctor, 2014; Julian, 2012). In light of the socioeconomic backgrounds of on-farm apprentices and host farmers, we begin to consider structural barriers to entry for individuals from low-wealth communities. These barriers transcend the individual or farm level and instead become indicators for issues within agricultural institutions as a whole.

In recent years, the cultural whiteness and color blindness within AAMs have also been critiqued by many (Allen, 2004; Etmanski, 2012; Guthman, 2008a; Hinrichs \& Allen, 2008; Sbicca, 2012; Slocum, 2007). As Slocum (2006), Allen (2004), and Guthman (2008a) have written, themes within AAM discourses unintentionally reproduce cultural whiteness and class privilege. Slocum (2007) writes that AAMs may be uninviting to historically underserved communities in part because AAMs celebrate an idealized past of "property, privilege, and paler skin" (p. 531). In this way, traditions that historically led to inequity are color-blindly reinforced and considered normative, which inadvertently reifies White privileged spaces within AAMs. Diverse cultural interpretations of the food system are not often visible within AAMs. Our study suggests that the on-farm apprenticeship, in its connection to AAM discourse and practice, is also subject to the same critique of cultural whiteness.

On-farm apprentices represented in our study normally lived on the farm for a tenured duration with low or no pay. Interviewees, meanwhile, discussed how the effects of this situation mean that participation was possible mainly for those with a "privileged background." The classed and privileged status of apprentices has been previously noted by others (Kalyuzhny, 2012; Pilgeram, 2011; Wood, 2013). Pondering our findings in the context of other literature, we now ask if the low or no pay for a specified duration was acting as an unintended barrier to participation for low-wealth groups, as it does for unpaid interns in other industries (Attfield \& Couture, 2014; Tucci, 2011). 
We intend to raise the question here for consideration.

As stated before, the cultural politics of learning and knowing play out in the apprenticeship experience. With this view, the specific elements of cultural whiteness and low or no pay within the onfarm apprenticeship may be institutionalized arrangements that reinforce class and privilege and also act as a barrier to entry into small-scale, diversified agriculture. This study gives us fodder for discussion in order to consider important structures and/or practices that may be socially (re)productive of inequitable learning spaces.

\section{Structural Barriers and Farm Labor}

More broadly, this questioning relates to the growing call to reimagine farm labor within the food system (Allen, 2008; Carolan, 2012; Cavalieri, 2011; Guptill, et al., 2013; Holmes, 2013). It is noted that farmworkers, although we depend on them for sustenance, are largely invisible within the U.S. food system (Guptill et al., 2013; Luna, 2014). As a result, farm work remains an occupational class with high poverty, high incidence of labor abuse, few worker protections, and low regulatory oversight (Holmes, 2013; Bon Appétit Management Company Foundation \& United Farm Workers, 2011). Many add that small-scale, sustainability oriented farming does not automatically guarantee a focus on socially just labor practices (Harrison \& Getz, 2015; Shreck, Getz, \& Feenstra, 2006). Meeting labor needs can be a significant barrier for beginning farmers (Gillespie \& Johnson, 2010; Ruhf, 2001), and volunteer labor, including onfarm apprenticeships, is occasionally touted as a solution (Kalyuzhny, 2012; Terry, 2014). Drawing upon our findings and others' work (see Pilgeram, 2011; Wood, 2013) we open space here to carefully discuss and problematize the way farm labor may be understood and (mis)appropriated within the realm of apprenticeships and AAMs.

To that end, our purpose here is not to present on-farm apprenticeships as a possible articulation of labor injustice and invisibility. Instead, we seek to query if the use of apprentices for inexpensive farm labor may be yet another symptom of a historically problematic agricultural system and labor situation in the United States. Farms, especially the small, diversified, and labor-intensive enterprises in our study, may sometimes come to rely on inexpensive or free labor in order to keep the farm financially afloat, a condition which could persist in future farm generations as a socially and culturally recursive response. As Althusser (2006) writes, the systemic framework that creates the social conditions for a given means of production will reproduce itself through sociocultural exchange. Beliefs beget practices, which beget policies (Goodman et al., 2012; Holmes, 2013). We conclude, then, that the on-farm apprenticeship is a somewhat problematic symptom of a larger systemic issue. The issue stems from the lack of favorable scale-appropriate and socially just agricultural policy that would enable farmers to thrive in a system that has resulted in socioeconomic and ecological excesses that cannot be sustained. This critique generally points to the ways in which agricultural subsidies are disproportionately dispersed to larger, commodity-based farms; publicly funded research efforts are often targeted to the advancement of technical solutions to production issues; and farm policy is oriented to support such initiatives as the $\mathrm{H}-2 \mathrm{~A}$ guestworker program (see Carolan, 2012, for good summary) in lieu of embracing grassroots labor and farmworker organizing. While the complex issues surrounding policy and farm labor justice is beyond the scope of this paper, we point to this thread in order to identify, problematize, and thus allow for a reimagining of this schema, and address issues in a way that improves agricultural opportunities by enabling AAMs, and the motivated individuals within them, to realize their transformative potential for social justice as well as sustainability in our food system.

\section{Conclusion}

This study illuminates the on-farm apprenticeship phenomenon, an increasingly popular expression of the burgeoning body of beginning-farmer policy and programming. The examination of this phenomenon highlighted questions regarding the privileged social status of on-farm apprentices and farmer hosts as participants in alternative agrifood movements (AAMs), in which the political 
discourses and values are reciprocally informed by their apprenticeship activity. On-farm apprenticeship programs, then, are best understood as embedded within AAMs. On-farm apprenticeships are therefore populated by motivated individuals who seek to critically engage with our agrifood system in order to improve it.

Farmers viewed apprentices as a source of inexpensive labor on their small, diversified, directmarketing farms. This underscores the need to critically examine the overarching structural conditions (political, cultural, economic, and otherwise) that make it difficult for individual farms to meet their labor needs. The apprenticeship model has been one way that small farmers have met demands for labor, but because the on-farm apprenticeships are embedded in AAMs, they share the critique of cultural whiteness and also provide low or no pay for a tenured duration. These factors could inadvertently contribute to low participation for historically underrepresented socioeconomic groups. Because on-farm apprenticeships can be an entry point into agriculture, this scenario may also limit participation in AAMs and agriculture more generally.

In light of our findings and this discussion, we make several recommendations for researchers, practitioners, and educators who are involved in planning and evaluating on-farm apprenticeships:

- Challenge cultural whiteness by incorporating principles and practices of dismantling racism into the repertoire and norms for agricultural educators and service providers who are involved in the design of on-farm and agricultural education programming.

- Consider strategies that enable farmers to hire apprentices at the equivalent of minimum wage with benefits, including placing due value on specific educational activities and any food and housing provided. At the same time, consider ways to supplement apprentices' educational activities through the land-grant system, programming initiatives, and programs that have had demonstrated success in providing such support (see, for example, Carey et al., 2006).
- Conduct critical inquiries into, and analysis of, scale-appropriate agricultural policy and economic considerations that may affect the profitability and/or competiveness of small, diversified farms, so they are able to better meet their labor needs in a fair and equitable manner.

Further research into this issue is imperative to better understand the labor needs of small, diversified farms, using the critical social justice lens called for in AAM discourse. Our study has provided empirical evidence that better defines these questions. By problematizing and improving upon the cultural whiteness and low or no pay of the apprenticeship model, and in light of farm apprenticeships' embeddedness in AAMs, we seek to address these two specific structural elements that affect the expression of social justice in on-farm apprenticeships, while examining how small farmers can meet their labor needs. By identifying these areas in need of improvement, and fine-tuning the on-farm apprenticeship model, apprenticeships may take their place in the future as an important pathway for aspiring and beginning farmers to surmount barriers and enter into food and farming systems, while staying firmly rooted in the principles of social justice.

\section{Acknowledgements}

Many thanks to Dr. Susan Magliaro and Dr. Rick Rudd for their valuable guidance throughout each phase of this study, and to the anonymous JAFSCD reviewers for their helpful comments and suggestions on this manuscript. We would also like to thank, sincerely and profusely, the anonymous participants in this study.

\section{References}

Ahearn, M. C. (2013). Beginning farmers and ranchers at a glance (Economic Bulletin No. 22). U.S. Department of Agriculture, Economic Research Service. Retrieved from http://dx.doi.org/10.2139/ssrn.2266443

Ahearn, M., \& Newton, D. (2009). Beginning farmers and ranchers (Economic Information Bulletin No. 53). Retrieved from http://www.ers.usda.gov/media/ 156049/eib53 1.pdf 
Ahearn, M. C., Yee, J., \& Korb, P. (2005). Effects of differing farm policies on farm structure and dynamics. American Journal of Agricultural Economics, 87(5), 1182-1189. http://dx.doi.org/10.1111/ j.1467-8276.2005.00805.x

Allen, P. (2004). Together at the table: Sustainability and sustenance in the American agrifood system. University Park: Pennsylvania State University Press.

Allen, P. (2008). Mining for justice in the food system: Perceptions, practices, and possibilities. Agriculture and Human Values, 25(2), 157-161. http://dx.doi.org/10.1007/s10460-008-9120-6

Althusser, L. (2006). Lenin and philosophy and other essays. Delhi: Aakar Books.

Attfield, J., \& Couture, I. (2014). An investigation into the status and implications of unpaid internships in Ontario. Victoria, British Columbia, Canada: University of Victoria.

Babbie, E. (1990). Survey research methods (2nd ed.). Belmont, California: Wadsworth Publishing.

Babbie, E. (2010). The practice of social research (12th ed.). Belmont, California: Wadsworth Publishing.

Bailey, M. J. \& Dynarski, S. M. (2011). Gains and gaps: Changing inequality in US college entry and completion (Working Paper No. 17633). http://dx.doi.org/10.3386/w17633

Bon Appétit Management Company Foundation \& United Farm Workers. (2011). Inventory of farmworker issues and protections in the United States. Retrieved from http://www.ufw.org/

Bourdieu, P. (1984). Distinction: A social critique of the judgement of taste. Cambridge, Massachusetts: Harvard University Press.

Broadway, M. (2009). Growing urban agriculture in North American cities: The example of Milwaukee. FOCUS on Geography, 52(3), 23-30. http://dx.doi.org/10.1111/j.19498535.2009.tb00251.x

Carey, E., Kelly, K., Hendrickson, M., Nagengast, D., Quinn, J., Volland, C., \& Kumar, L. (2006). The Growing Growers Training Program: An apprenticeship program for market gardeners serving Kansas City. HortTechnology, 16(3), 439-443. Retrieved from http://horttech.ashspublications.org/

Carlisle, L. (2014). Critical agrarianism. Renewable Agriculture and Food Systems, 29(2), 135-145. http://dx.doi.org/10.1017/S1742170512000427
Carolan, M. (2012). The sociology of food and agriculture. Abindon, Oxon, UK: Routledge.

Cavalieri, S. (2011). The eyes that blind us: The overlooked phenomenon of trafficking into the agricultural sector. Northern Illinois University Law Review, 31, 501-519. Available at https://traffickingresourcecenter.org/sites/default /files/The Eyes that Blind Us.pdf

Clancy, K., \& Ruhf, K. (2010). Is local enough? Some arguments for regional food systems. Choices, 25(1). Retrieved from http://www.choicesmagazine.org/

Constance, D. H., Renard, M.-C., \& Rivera-Ferre, M. G. (2014). Alternative agrifood movements: Patterns of convergence and divergence (Research in Rural Sociology and Development, Vol. 21). Bingley, UK: Emerald Group Publishing. http://dx.doi.org/10.1108/ $\underline{\mathrm{S} 1057-192220140000021024}$

Creswell, J. W. (2009). Research design: Qualitative, quantitative, and mixed methods approaches (3rd ed.). Thousand Oaks, California: Sage Publications.

DeNavas-Walt, C., \& Proctor, B. D. (2014). Income and poverty in the United States: 2013, current population reports. Retrieved from https://www.census.gov/ content/dam/Census/library/publications/2014/ demo/p60-249.pdf

Dewey, J. (1938/1986). Experience and education. The Educational Forum, 50(3), 241-252. http://dx.doi.org/10.1080/00131728609335764

Dimitri, C., Effland, A., \& Conklin, N. (2005). The 20th century transformation of US agriculture and farm policy (Economic Information Bulletin No. 3). Retrieved from http://www.ers.usda.gov/media/259572/ eib3 1 .pdf

Endres, A. B., \& Armstrong, R. (2014). Community supported agriculture and community labor: Constructing a new model to unite volunteers and employers. Southwestern Law Review, 43, 371-396. Retrieved from http://www.swlaw.edu/

Etmanski, C. (2012). A critical race and class analysis of learning in the organic farming movement. Australian Journal of Adult Learning, 52(3), 484-506. Retrieved from https://ala.asn.au/

Feenstra, G. (2002). Creating space for sustainable food systems: Lessons from the field. Agriculture and Human Values, 19(2), 99-106. http://dx.doi.org/10.1023/A:1016095421310

Foley, G. (1999). Learning in social action: A contribution to understanding informal education. New York: Zed Books. 
Freire, P. (1972). Pedagogy of the oppressed. New York: Continuum International Publishing Group.

Freire, P. (2005). Teachers as cultural workers: Letters to those who dare teach (Expanded ed.). Boulder, Colorado: Westview Press.

Gillespie, G. W., Jr., \& Johnson, S. E. (2010). Success in farm start-ups in the Northeastern United States. Journal of Agriculture, Food Systems, and Community Development, 1(1), 31-48. http://dx.doi.org/10.5304/jafscd.2010.011.008

Giroux, H. (1992). Border crossings: Cultural workers and the politics of education. New York: Routledge.

Goodman, D., DuPuis, E. M., \& Goodman, M. K. (2012). Alternative food networks: Knowledge, practice, and politics. New York: Routledge.

Greene, J. C. (2007). Mixed methods in social inquiry. Hoboken, New Jersey: John Wiley \& Sons.

Guptill, A., Copelton, D. \& Lucal, B. (2013). Food and society: Principles and paradoxes. John Wiley \& Sons.

Guthman, J. (2008a). "If they only knew": Color blindness and universalism in California alternative food institutions. The Professional Geographer, 60(3), 387-397.

http://dx.doi.org/10.1080/00330120802013679

Guthman, J. (2008b). Bringing good food to others: Investigating the subjects of alternative food practice. Cultural Geographies, 15(4), 431-447. http://dx.doi.org/10.1177/1474474008094315

Hamilton, N. D. (2011). America's new agrarians: Policy opportunities and legal innovations to support new farmers. Fordham Environmental Law Review, 22(3), 101-140. Available at http://papers.ssrn.com/ sol3/papers.cfm?abstract id $=2025197$

Hamm, M. W., \& Bellows, A. C. (2003). Community food security and nutrition educators. Journal of Nutrition Education and Behavior, 35(1), 37-43. http://dx.doi.org/10.1016/S1499-4046(06)60325-4

Harrison, J. L., \& Getz, C. (2015). Farm size and job quality: Mixed-methods studies of hired farm work in California and Wisconsin. Agriculture and Human Values, 32(4), 617-634. http://dx.doi.org/10.1007/s10460-014-9575-6

Henderson, E., \& North, K. (2011). Whole-farm planning: Ecological imperatives, personal values, and economics. White River Junction, Vermont: Chelsea Green Publishing.

Hinrichs, C. C., \& Allen, P. (2008). Selective patronage and social justice: Local food consumer campaigns in historical context. Journal of Agricultural and Environmental Ethics, 21(4), 329-352. http://dx.doi.org/10.1007/s10806-008-9089-6

Holmes, S. (2013). Fresh fruit, broken bodies: Migrant farmworkers in the United States. Berkeley and Los Angeles: University of California Press.

Hsieh, H.-F., \& Shannon, S. E. (2005). Three approaches to qualitative content analysis. Qualitative Health Research, 15(9), 1277-1288. http://dx.doi.org/10.1177/1049732305276687

Jones, D. (1999). Internships in sustainable farming: $A$ handbook for farmers. New York: Northeast Organic Farming Association of New York.

Julian, T. (2012). Work-life earnings by field of degree and occupation for people with a bachelor's degree: 2011 (Report No. ACSBR/11-04). Retrieved from https://www.census.gov/prod/2012pubs/acsbr1104.pdf

Kalyuzhny, J. (2012). Cultivating the next generation: Why farming internships should be legal. San Joaquin Agricultural Law Review, 21(1), 131-154. Retrieved from http://www.sjcl.edu/index.php/volumes

Lather, P. (1991). Getting smart: Feminist research and pedagogy with/in the postmodern. New York: Routledge.

Lave, J. (1988). Cognition in practice: Mind, mathematics and culture in everyday life. Cambridge, UK: Cambridge University Press. http://dx.doi.org/10.1017/cbo9780511609268

Lavin, C. (2009). Pollanated politics, or, the neoliberal's dilemma [Blog post]. Retrieved from https:// politicsandculture.org/2009/11/03/chad-lavinpollanated-politics-or-the-neoliberal's-dilemma/

Leis, A., Whittington, S., Bennet, M., \& Kleinhenz, M. (2011). Student farms at United States colleges and universities: Insights gained from a survey of the farm managers. NACTA Journal, 55(1), 9-15. Retrieved from https://www.nactateachers.org/

Lincoln, Y. S., \& Guba, E. G. (2000). Paradigmatic controversies, contradictions, and emerging confluences. In N. K. Denzin \& Y. S. Lincoln (Eds.), Handbook of qualitative research (2nd ed., pp. 163-188). Thousand Oaks, California: Sage Publications.

Luna, G. T. (2014). The dominion of agricultural sustainability: Invisible farm laborers. The Wisconsin Law Review, 2014(2), 265-288. Retrieved from http://wisconsinlawreview.org/ 
Lyson, T. A. (2004). Civic agriculture: Reconnecting farm, food, and community. Medford, Massachusetts: Tufts University Press.

Meyer, L., Hunter, J., Katchova, A., Lovett, S., Thilmany, D., Sullins, M., \& Card, A. (2011). Approaching beginning farmers as a new stakeholder for extension. Choices, 26(2). Retrieved from http://www.choicesmagazine.org/

Mills-Novoa, M. (2011). Sustaining family farming through mentoring: A toolkit for National Family Farm Coalition members. Retrieved from http://www.nffc.net/ Issues/LocalFood/NFFC Mentoring Report2011. final.pdf

Nickerson, C., \& Hand, M. (2009). Participation in conservation programs by targeted farmers: Beginning limitedresource, and socially disadvantaged operators' enrollment trends (Economic Information Bulletin No. 62). United States Department of Agriculture, Economic Research Service. http://dx.doi.org/10.2139/ssrn.1551930

Niewolny, K. (2007). Growing new farmers or producing new producers? A critical discourse analysis of the Growing New Farmers Consortium, 2000-2005. Unpublished doctoral dissertation, Cornell University.

Niewolny, K. L., \& Lillard, P. T. (2010). Expanding the boundaries of beginning farmer training and program development: A review of contemporary initiatives to cultivate a new generation of American farmers. Journal of Agriculture, Food Systems, and Community Development, 1(1), 65-88. http://dx.doi.org/10.5304/jafscd.2010.011.010

Niewolny, K., \& Wilson, A. (2007). Economic knowledge production of the growing new farmers consortium, 20002005: A critical discourse analysis of adult agricultural education. Paper presented at the Annual Adult Education Research Conference. Retrieved from http://newprairiepress.org/aerc/2007/papers/77/

Paradise, R., \& Rogoff, B. (2009). Side by side: Learning by observing and pitching in. Ethos, 37(1), 102-138. http://dx.doi.org/10.1111/j.1548-1352.2009. 01033.x

Parr, D. M., \& Trexler, C. J. (2011). Students' experiential learning and use of student farms in sustainable agriculture education. Journal of Natural Resources and Life Sciences Education, 40(1), 172-180. http://dx.doi.org/10.4195/inrlse.2009.0047u

Parsons, R., Ruhf, K., Stevenson, G. W., Baker, J., Bell, M., Epley, E.,...Keller, J. (2010). Research report and recommendations from the FarmL ASTS Project.
Retrieved June 5, 2015, from

http://www.uvm.edu/farmlasts/

Pilgeram, R. (2011). "The only thing that isn't sustainable...is the farmer": Social sustainability and the politics of class among Pacific Northwest farmers engaged in sustainable farming. Rural Sociology, 76(3), 375-393. http://dx.doi.org/ 10.1111/j.1549-0831.2011.00051.x

Powell, M. (2007). Western Sustainable Agriculture \& Education (SARE) farm internship handbook. Available at https://attra.ncat.org/intern handbook/ handbook.htm

Ruhf, K. Z. (2001). Northeast new farmers: Opportunities for policy development. Retrieved from http://www.small farm.org/uploads/uploads/Files/Policy Backgrou nd Paper.pdf

Sbicca, J. (2012). Growing food justice by planting an anti-oppression foundation: Opportunities and obstacles for a budding food justice movement. Agriculture and Human Values, 29(4), 455-466. http://dx.doi.org/10.1007/s10460-012-9363-0

Shreck, A., Getz, C., \& Feenstra, G. (2006). Social sustainability, farm labor, and organic agriculture: Findings from an exploratory analysis. Agriculture and Human Values, 23(4), 439-449. http://dx.doi.org/10.1007/s10460-006-9016-2

Slocum, R. (2006). Anti-racist practice and the work of community food organizations. Antipode, 38(2), 327-349. http://dx.doi.org/10.1111/j.1467$\underline{8330.2006 .00582 . x}$

Slocum, R. (2007). Whiteness, space, and alternative food practice. Geoforum, 38(3), 520-533. http://dx.doi.org/10.1016/j.geoforum.2006.10.006

Smith, M. (2005). The on-farm mentor's guide: Practical approaches to teaching on the farm. Belchertown, Massachusetts: New England Small Farm Institute.

Sureshwaran, S., \& Ritchie, S. (2011). U.S. farm bill resources and programs for beginning farmers. Choices, 26(2). Retrieved from http://www.choicesmagazine.org/

Terry, W. (2014). Solving labor problems and building capacity in sustainable agriculture through volunteer tourism. Annals of Tourism Research, 49, 94-107. http://dx.doi.org/10.1016/j.annals.2014.09.001

Thilmany, D., \& Sureshwaran, S. (2011). Theme overview: Innovations to support beginning farmers and ranchers. Choices, 26(2). Retrieved from http://www.choicesmagazine.org/ 
Tucci, A. J. (2011). Worthy exemption? Examining how the DOL should apply the FLSA to unpaid interns at nonprofits and public agencies. Iowa Law Review, 97, 1363-1392. http://ilr.law.uiowa.edu/

U.S. Department of Agriculture, National Agricultural Statistics Service [USDA NASS]. (2009). 2007

Census of Agriculture: United States summary and state data (Vol. 1, Geographic Area Series, Part 51, AC07-A-51). Washington, D.C.: Author.
USDA NASS. (2014). 2012 Census of Agriculture: United States summary and state data (Vol. 1, Geographic Area Series, Part 51, AC-12-A-51). Washington, D.C.: Author.

Wood, K. F. (2013). Laboring to learn and learning to labor: Experiences of farm interns on sustainable

farms (Unpublished doctoral dissertation). Pennsylvania State University, State College, Pennsylvania. 


\section{Appendix A. Interview Protocol}

\section{On-Farm Apprenticeship Learning Research Project Interview Protocol}

[Share consent form.]

[Read aloud the following:]

"I am [name], and thank you very much for your participation in this research to explore and describe on-farm apprenticeship learning in Virginia. This interview will be audio-recorded to ensure accuracy, and I will take a few notes to keep pace with the interview. There are no right or wrong answers. In all written documents that result from this interview, a pseudonym, or fake name, will be used, and identifying characteristics will be removed, to ensure your anonymity. This interview is completely voluntary. You are under no obligation to answer any question, and are free to leave at any time."

\section{Interview Questions for Farmer Educators}

1. Please tell me a little about yourself and your background. (Where are you from? How long have you been on the farm?)

2. Describe the first time you ever identified yourself as a farmer.

3. Please describe to me how the typical learning experience occurs for apprentices on your farm.

4. What is your communication with the apprentices like?

5. How often do the apprentices get exposure to the larger farming community?

6. How does their farm experience change the way apprentices seem to see themselves as farmers?

7. Is there anything else you would like to share that you haven't already?

8. Who else should I visit to learn more about my questions?

\section{Interview Questions for On-farm Apprentices}

1. Please tell me a little about yourself and your background. (Where are you from? How long have you been on the farm?)

2. Please describe to me how the typical learning experience occurs through your apprenticeship.

3. What are some of the most important things you learned through your apprenticeship, and how did you learn these?

4. How did your apprenticeship/internship change the way you see yourself as a farmer?

5. Tell me about your relationship with the farmer and other apprentices.

6. If you could design your own apprenticeship or internship experience, what would it look like?

7. Please tell me a bit about the next steps for you. (Do you think you will start farming? Why or why not?)

8. Is there anything else you would like to share that you haven't already?

9. Who else should I visit to learn more about my questions?

[Thank you for your time.] 


\section{Appendix B: Survey Instrument}

\section{The On-Farm Apprenticeship Research Project Survey}

Who should take this survey?

Please fill out and return this survey if you are one of the primary owners or managers of a farm that has an onfarm apprenticeship or internship program, or a farm that has hosted apprentices and/or interns.

For purposes of this survey, an on-farm apprentice is someone who:

- May be referred to as an apprentice, intern, or on-farm student,

- Over 18 years of age,

- Works on the farm for a specified length of time,

- Can be paid or unpaid, and

- There is an expressed agreement that you would teach them how to farm.

Thank you very much for your time and attention to this survey about on-farm apprenticeship and internship programs in Virginia. This is an academic research project through Virginia Tech.

Your answers are very important in determining how apprenticeships are currently being structured, common practices and how learning occurs in apprenticeship programs, and the types of farms that host apprentices. In the long run, your answers can help inform how Agricultural Extension might best serve and support these programs to advance agriculture in Virginia.

You will be asked questions relating to the apprentices, any practices, policies and procedures that support apprentices and interns, educational strategies, and information about you and your farm. Your participation in this survey is completely voluntary, and you are under no obligation to answer any question, for any reason. Your survey is completely anonymous, and no identifying characteristics will be used in any way for this survey. 


\section{Part 1: Apprentice Information}

First, please answer the below questions about the apprentices on your farm.

1. What word do you use to describe your apprentices (for example: intern, apprentice, wage employee with educational component, etc.)?

2. How many years have you had apprentices on your farm?

3. How old is the typical apprentice? (years)

4. How many apprentices TOTAL have you had on your farm since you began farming?

5. Of the apprentices you've had, please write how many were:

$$
\text { female }
$$

male

6. Of the apprentices you've had, please write how many were:

American Indian or Alaska Native

Asian

Black or African American

Native Hawaiian or Other Pacific Islander

Spanish, Hispanic, or Latino Origin

White

7. Of the apprentices you've had, please write how many had the below education level:

Some High School

High School Diploma

Some College

Associate's Degree

Bachelor's Degree

Vocational/Trade School

Some Graduate School

Master's Degree

$\mathrm{PhD}$

Other

Unsure or I don't know

8. How many years of farming experience does your typical apprentice have before they start at your farm? (years)

9. How many apprentices do you usually have on the farm at the same time? 


\section{Part 2: Apprenticeship Program Details}

Next, please provide some information pertaining to the apprenticeship program on your farm.

10. Apprentices stay with the farm for (on average) how many weeks?

11. Please rate your motivations for wanting apprentices on your farm, on a scale of "very important" to "not important."

\begin{tabular}{|l|l|l|l|l|}
\hline Check the box: & $\begin{array}{c}\text { Very } \\
\text { Important }\end{array}$ & $\begin{array}{c}\text { Somewhat } \\
\text { Important }\end{array}$ & $\begin{array}{c}\text { Somewhat } \\
\text { Not } \\
\text { Important }\end{array}$ & $\begin{array}{c}\text { Not } \\
\text { Important }\end{array}$ \\
\hline I need labor for my farm. & & & & \\
\hline I like working with others. & & & & \\
\hline I enjoy teaching. & & & & \\
\hline I want to help create educated consumers. & & & & \\
\hline $\begin{array}{l}\text { I had a good learning experience and want to provide } \\
\text { the same opportunity to others. }\end{array}$ & & & & \\
\hline I want to share the farming lifestyle with others. & & & & \\
\hline I want to help train the next generation of farmers. & & & & \\
\hline I like the energy of having “new blood” on my farm. & & & & \\
\hline I want to spend time with others who enjoy farming. & & & & \\
\hline Other motivations (please list): & & & & \\
\hline
\end{tabular}

Source: The On-Farm Mentor's Guide: Practical Approaches to Teaching on the Farm, by Miranda Smith (2006), published by New England Small Farm Institute.

12. If you have used any outlet for advertising your apprenticeship program, which did you use? (check one) ATTRA website OTHER website (please list below) Social media (Facebook, blogs, listserv, etc.)

_ Ad in newspaper or magazine

Flyers or brochures

Word of mouth

OTHER (please list below)

If you used "OTHER" outlets for advertising, please list:

13. Have you consulted a handbook or guide for information to help you with your apprenticeship program? (check one)

yes _no

IF YES, which handbook or guide did you use? 
14. Have you sought advice or guidance from an agricultural organization to help you with your apprenticeship program? (check one)

_yes_no

IF YES, please list which one(s):

15. Have you sought advice or guidance from another farmer to help you with your apprenticeship program? (check one)

_yes _no

IF YES, what was your relation (ex: friend, relative, etc.)?

16. Have you sought advice or guidance from the Extension Service to help you with your apprenticeship program? (check one)

yes _no

IF YES, what was your relation (ex: friend, relative, etc.)?

17. If you had any OTHER sources of advice or guidance that you sought to help you with your apprenticeship program, please list here:

18. Next, please let us know about what kinds of practices, policies and procedures you have on your farm to support your apprenticeship program.

Please rate how much you agree with the following statements, on a scale of "strongly agree" to "strongly disagree."

\begin{tabular}{|l|l|l|l|l|}
\hline Check the box: & $\begin{array}{c}\text { Strongly } \\
\text { Agree }\end{array}$ & $\begin{array}{c}\text { Somewhat } \\
\text { Agree }\end{array}$ & $\begin{array}{c}\text { Somewhat } \\
\text { Disagree }\end{array}$ & $\begin{array}{c}\text { Strongly } \\
\text { Disagree }\end{array}$ \\
\hline $\begin{array}{l}\text { I have an established application process, which includes a } \\
\text { written application. }\end{array}$ & & & & \\
\hline $\begin{array}{l}\text { I require all prospective apprentices to visit the farm for an } \\
\text { interview. }\end{array}$ & & & & \\
\hline $\begin{array}{l}\text { I require a written, signed, work agreement with } \\
\text { apprentices. }\end{array}$ & & & & \\
\hline $\begin{array}{l}\text { I provide stipends or other monetary compensation for } \\
\text { apprentices. }\end{array}$ & & & & \\
\hline I have an established orientation process. & & & \\
\hline $\begin{array}{l}\text { I have a probationary or trial period when apprentices first } \\
\text { start, to make sure they are a good fit for the position. }\end{array}$ & & & \\
\hline $\begin{array}{l}\text { I provide incentives (monetary or in-kind) for apprentices to } \\
\text { stay for the full season. }\end{array}$ & & & & \\
\hline $\begin{array}{l}\text { I have regularly scheduled meetings with apprentices to } \\
\text { discuss the farm work. }\end{array}$ & & & & \\
\hline $\begin{array}{l}\text { I include apprentices in marketing activities (farmers } \\
\text { market, roadside stand, etc.). }\end{array}$ & & & & \\
\hline $\begin{array}{l}\text { I make sure apprentices learn how to do a wide variety of } \\
\text { tasks on the farm. }\end{array}$ & & & & \\
\hline $\begin{array}{l}\text { I have regularly scheduled check-ins to receive feedback } \\
\text { from apprentices. }\end{array}$ & & & & \\
\hline
\end{tabular}


19. What kind of housing do you provide to apprentices? (check one)

I do not provide housing.

On the farm in my home.

On the farm in a separate building from my home.

We have an arrangement to provide housing off the farm.

Other:

20. Do you share kitchen facilities with apprentices? (check one)

yes no

21. Do you share bathroom facilities with apprentices? (check one) yes no

22. Next, please let us know what kind of teaching strategies you employ on your farm to teach apprentices.

How often do you provide the following to your apprentices? Please rate on a scale of "very often" to "never."

\begin{tabular}{|l|l|l|l|l|}
\hline Check the box: & Often & Sometimes & Rarely & Never \\
\hline Verbal explanations of new tasks & & & & \\
\hline Hands-on demonstrations for new tasks & & & & \\
\hline On-farm special workshops & & & & \\
\hline Tours of your farm & & & & \\
\hline Tours of other farms & & & & \\
\hline Farmer-led discussions about farming & & & & \\
\hline $\begin{array}{l}\text { Discussion time for apprentices just to talk with each } \\
\text { other about farming }\end{array}$ & & & & \\
\hline Scheduled lessons or meetings with other farmers & & & & \\
\hline Written worksheets or other curriculum on farming & & & & \\
\hline $\begin{array}{l}\text { Have apprentices journal or do other writing about } \\
\text { farming }\end{array}$ & & & & \\
\hline Have apprentices go with you on errands & & & \\
\hline Use of your farming books or other literature & & & \\
\hline Use of the internet to research farming topics & & & & \\
\hline Indoor classroom-style classes on your farm & & & & \\
\hline Work side-by-side with the apprentices & & & & \\
\hline $\begin{array}{l}\text { Personalized feedback to each apprentice after seeing } \\
\text { how they perform a new task }\end{array}$ & & & & \\
\hline Discuss my philosophy of farming with apprentices & & & & \\
\hline Explaining the “why" not just the "how" of farming & & & & \\
\hline Shared meals or social events with apprentices & & & \\
\hline Bring apprentices to other farming classes or workshops & & & \\
\hline
\end{tabular}


23. Next, please inform us of the attributes and performance of apprentices on your farm.

Please rate how much you agree with the following statements, on a scale of "strongly agree" to "strongly disagree."

\begin{tabular}{|l|l|l|l|l|}
\hline Check the box: & $\begin{array}{c}\text { Strongly } \\
\text { Agree }\end{array}$ & $\begin{array}{c}\text { Somewhat } \\
\text { Agree }\end{array}$ & $\begin{array}{c}\text { Somewhat } \\
\text { Disagree }\end{array}$ & $\begin{array}{c}\text { Strongly } \\
\text { Disagree }\end{array}$ \\
\hline $\begin{array}{l}\text { Apprentices are accustomed to hard physical labor } \\
\text { before they start. }\end{array}$ & & & & \\
\hline $\begin{array}{l}\text { Apprentices have a realistic picture of the realities of } \\
\text { farming before they start. }\end{array}$ & & & & \\
\hline $\begin{array}{l}\text { Apprentices are accustomed to life on the farm before } \\
\text { they start. }\end{array}$ & & & & \\
\hline Apprentices are from a farming background. & & & \\
\hline $\begin{array}{l}\text { Apprentices have farmland in the family that they may } \\
\text { inherit. }\end{array}$ & & & & \\
\hline $\begin{array}{l}\text { Most apprentices live on the farm for the duration of } \\
\text { their apprenticeship. }\end{array}$ & & & \\
\hline $\begin{array}{l}\text { Most apprentices are certain that they want to start their } \\
\text { own farm. }\end{array}$ & & & \\
\hline $\begin{array}{l}\text { Apprentices develop their own philosophy of farming } \\
\text { during their apprenticeship. }\end{array}$ & & & \\
\hline $\begin{array}{l}\text { As a result of the apprenticeship, apprentices become } \\
\text { comfortable in their role as farmer. }\end{array}$ & & & \\
\hline $\begin{array}{l}\text { As a result of the apprenticeship, most come to see } \\
\text { themselves as farmers. }\end{array}$ & & & & \\
\hline $\begin{array}{l}\text { I am overall satisfied with the work of apprentices on the } \\
\text { farm. }\end{array}$ & & & & \\
\hline
\end{tabular}


24. Next, please inform us policies, practices and procedures you may use after an apprenticeship has finished.

Please rate how much you agree with the following statements, on a scale of "strongly agree" to "strongly disagree."

\begin{tabular}{|l|l|l|l|l|}
\hline Check the box: & $\begin{array}{c}\text { Strongly } \\
\text { Agree }\end{array}$ & $\begin{array}{c}\text { Somewhat } \\
\text { Agree }\end{array}$ & $\begin{array}{c}\text { Somewhat } \\
\text { Disagree }\end{array}$ & $\begin{array}{c}\text { Strongly } \\
\text { Disagree }\end{array}$ \\
\hline $\begin{array}{l}\text { My farm follows up with apprentices after they finish their } \\
\text { apprenticeships. }\end{array}$ & & & & \\
\hline $\begin{array}{l}\text { I give apprentices farming advice after they complete their } \\
\text { program. }\end{array}$ & & & & \\
\hline I talk to and see former apprentices. & & & & \\
\hline
\end{tabular}

25. Have any of your apprentices gone on to start their own farms? (check one)

$$
\text { _yes_no _ _ I don't know }
$$

a. If YES, how many apprentices have gone on to start their own farms?

b. If YES, is their farm located in Virginia? (check one) yes no I don't know

c. If YES, do they produce some or all of the same agricultural products as you do? (check one)

_yes_no _ _ l don't know




\section{Part 3: Farm/Farmer Background}

Finally, please answer the following background questions about you and your farm.

26. Are you the principle operator of this farm? (check one)

yes no

If NO, what is your role?

27. I am:_female_male (check one)

28. Please check the category that best describes you (check one):

American Indian or Alaska Native

Asian

Black or African American

Native Hawaiian or Other Pacific Islander

Spanish, Hispanic, or Latino Origin

White

29. In what year did you begin to operate or manage any part of this farm?

30. What is your age at the time of this survey?

31. How many years have you been farming?

32. I have had the following training in agriculture (check all that apply):

Grew up on a farm.

Served on a farm as an apprentice.

Worked on a farm as a farm worker.

Had some academic training in farming (in high school, college, etc.)

Had some professional training in farming (workshops, community programs, etc.)

Other

a. What is your highest level of formal education completed? (check one)

\begin{tabular}{l} 
Some High School \\
_ High School Diploma \\
_ Some College \\
_ Associate's Degree \\
_ Vocational/Trade School \\
_ Bachelor's Degree \\
_ Some Graduate School \\
_ Master's Degree \\
P PhD \\
\hline Other_
\end{tabular}

33. What were your farm's approximate annual sales this past season? \$ 
34. What market outlets do you use? (check all that apply)

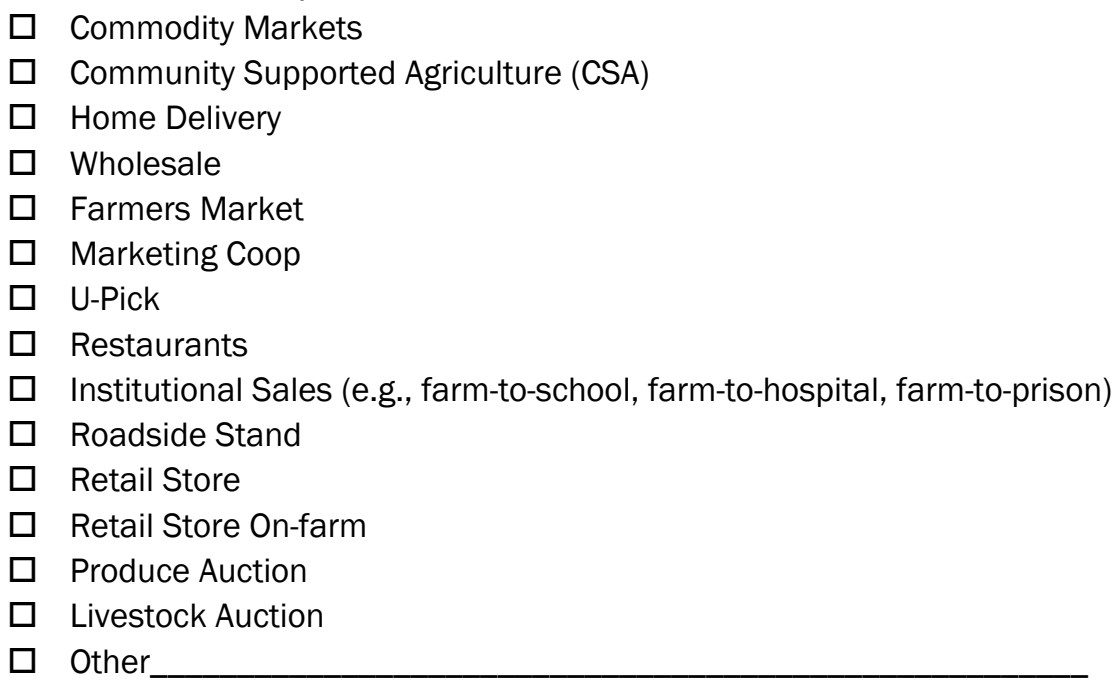

35. What do you produce commercially on your farm? (check all that apply)
$\square$ Soybeans
$\square$ Corn for grain
$\square$ Wheat for grain
$\square$ Grains, oilseeds, dry beans, and dry peas
$\square$ Tobacco
Cotton and cottonseed
$\square$ Vegetables, melons, potatoes and sweet potatoes
$\square$ Fruits, tree nuts, and berries
$\square$ Nursery, greenhouse, floriculture, and sod
$\square$ Cut Christmas trees and short-rotation woody crops
$\square$ Other crops and hay
$\square$ Poultry and eggs
$\square$ Cattle and calves
Milk and other dairy products from cows
Hogs and pigs
Sheep, goats, and their products
$\square$ Horses, ponies, mules, burros, and donkeys
Aquaculture
$\square$ Forage-land used for all hay and haylage, grass silage, and green
$\square$ Other animals and other animal products

36. My farm is: (check all that apply)

$\square$ Individually operated

$\square$ Family-operated

Operated in a business partnership with nonfamily members

37. County and state in which your farm is located (COUNTY, STATE) 
38. How many acres of farm land do you LEASE? OWN?

39. Would you be interested in participating in a 60-minute interview about your experiences with apprentices, at a time and place that is convenient for you?

Checking "yes" does NOT obligate you to participate in an interview. (check one) _yes no

IF YES, you may leave your contact information, below. By sharing your contact information, you are agreeing to be contacted by a Virginia Tech researcher, who will invite you to schedule an interview at a time and place that is convenient for you. Your survey responses will remain anonymous.

Name

Phone Number

Email Address

40. Please write below any comments or anything else you wish to share about on-farm apprenticeships:

Thank you very much for your time. Please return this survey to: Lorien MacAuley at 228 Litton-Reaves Hall, 175 West Campus Drive, Virginia Tech; Blacksburg, Virginia 24061 USA; 703-789-7748; lorien@vt.edu. If you would like to learn more about the On-Farm Apprenticeship Research Project, please contact Lorien MacAuley at 228 Litton-Reaves Hall, 175 West Campus Drive, Virginia Tech; Blacksburg, Virginia 24061 USA; 703-789-7748; lorien@vt.edu.

This is academic research through Virginia Tech. If you have complaints, suggestions, or questions about your rights as a research volunteer, please contact the staff of Virginia Tech's Institutional Review Board at 540-231-4991. For all other inquiries, please contact Lorien MacAuley at the above contact information. 